\title{
The Antarctic contribution to Holocene global sea level rise
}

\author{
Ólafur Ingólfsson \& Christian Hjort
}

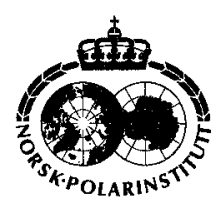

\begin{abstract}
The Holocene glacial and climatic development in Antarctica differed considerably from that in the Northern Hemisphere. Initial deglaciation of inner shelf and adjacent land areas in Antarctica dates back to between 10-8 Kya, when most Northern Hemisphere ice sheets had already disappeared or diminished considerably. The continued deglaciation of currently ice-free land in Antarctica occurred gradually between ca. 8-5 Kya. A large southern portion of the marine-based Ross Ice Sheet disintegrated during this late deglaciation phase. Some currently ice-free areas were deglaciated as late as $3 \mathrm{Kya}$. Between $8-5 \mathrm{Kya}$, global glacio-eustatically driven sea level rose by $10-17 \mathrm{~m}$, with $4-8 \mathrm{~m}$ of this increase occurring after 7 Kya. Since the Northern Hemisphere ice sheets had practically disappeared by $8-7$ Kya, we suggest that Antarctic deglaciation caused a considerable part of the global sea level rise between 8-7 Kya, and most of it between 7-5 Kya. The global mid-Holocene sea level high stand, broadly dated to between 8-4 Kya, and the Littorina-Tapes transgressions in Scandinavia and simultaneous transgressions recorded from sites e.g. in Svalbard and Greenland, dated to 7-5 Kya, probably reflect input of meltwater from the Antarctic deglaciation.
\end{abstract}

Ó. Ingólfsson, Gothenburg University, Earth Sciences Centre. Box 460, SE-405 30 Göteborg, Sweden; C. Hjort, Dept. of Quaternary Geology, Lund University, Sölvegatan 13, SE-223 62 Lund, Sweden.

\section{Introduction}

The modern Antarctic Ice Sheet (Fig. 1) covers an area of ca. $13.6 \times 10^{6} \mathrm{~km}^{2}$, and consists of roughly $29 \times 10^{6} \mathrm{~km}^{3}$ of grounded ice, with a total potential effect on sea level rise of about $66 \mathrm{~m}$ (Drewry et al. 1982; Denton et al. 1991). The role of Antarctic glacial ice as a meltwater source for global sea level rise since the Last Glacial Maximum (LGM) is controversial (Andrews 1992). Estimates range from as little as $0.5-2.5 \mathrm{~m}$ (Colhoun et al. 1992) to $37 \mathrm{~m}$ (Nakada \& Lambeck 1988), depending on whether calculations are based on minimum or maximum reconstruction of LGM-ice volumes in Antarctica. A number of appraisals put the Antarctic contribution to global sea level rise since LGM on the order of 12-26 m (Hughes et al. 1981; Huybrechts 1990a, b; Tushingham \& Peltier 1991; Peltier 1994; Clark et al. 1996). This is out of the total estimated global sea level rise of $120 \pm 20 \mathrm{~m}$ since LGM (e.g. Chappell \& Shackleton 1986; Fairbanks 1989; Peltier 1994).

The timing of LGM in Antarctica has not been precisely determined. It has been radiocarbon dated to 20-17 Kya (thousands of years before present) in the western Ross Sea area (Stuiver et al. 1981; Anderson et al. 1992; Kellogg et al. 1996; Licht et al. 1996), to 14 Kya in Taylor Valley, southern Victoria Land (Hall 1997), and to $\geq 17$ and $\geq 14$ Kya off East Antarctica and the Antarctic Peninsula, respectively (Banfield \& Anderson 1995; Harris et al. in press). Most authors assume that LGM roughly coincides with the lowest global sea level stand at 20-18 Kya.

In order to make a fair estimate of the Antarctic contribution to global sea level rise since LGM, the overall ice volume at LGM needs to be established. However, existing appraisals are controversial. One category of estimates suggests that marginal domes of the Antarctic Ice Sheet were 500-1000 m thicker than at present and that ice extended to the shelf break around most of the continent (Clark \& Lingle 1979; Denton 1979; Hughes et al. 1981; Zhang 1992). Hughes et al. (1981) calculated the volume of grounded ice in Antarctica at LGM to have been $37 \times 10^{6} \mathrm{~km}^{3}$, compared to roughly $29 \times 10^{6} \mathrm{~km}^{3}$ today, and suggested that the difference of $8 \times 10^{6} \mathrm{~km}^{3}$ equalled about $24 \mathrm{~m}$ of global sea 


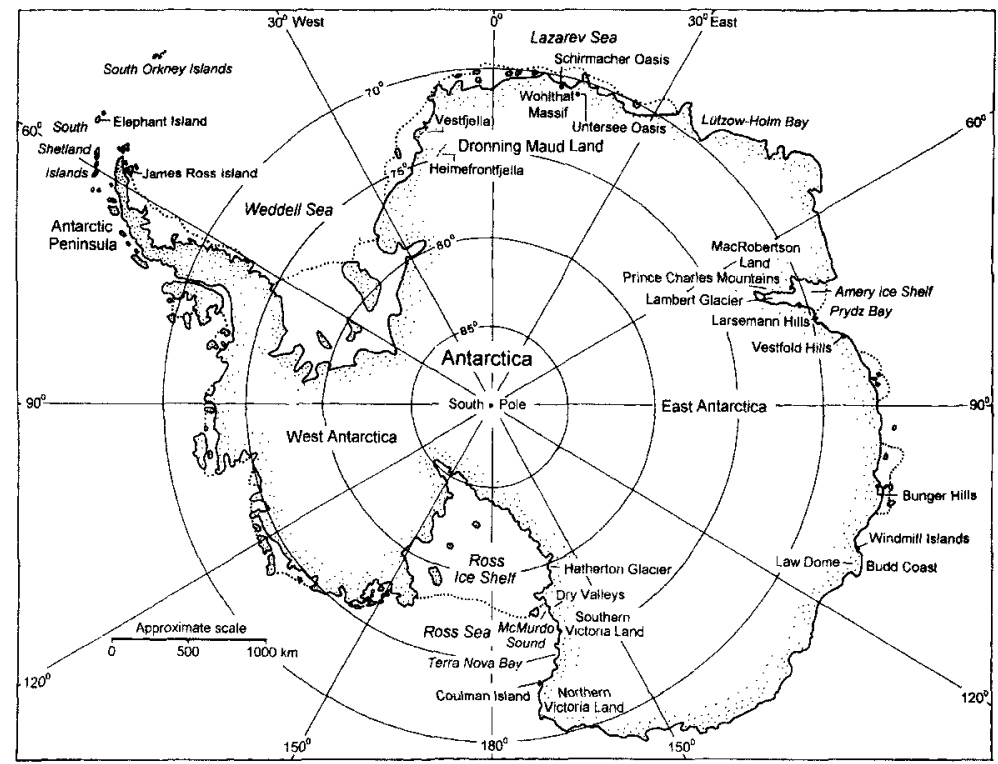

Fig. 1. Map of Antarctica.

level lowering at LGM. Their reconstruction was based on the assumptions that the East Antarctic Ice Sheet's peripheral domes thickened considerably and expanded towards the shelf break, and that the West Antarctic Ice Sheet was considerably expanded relative to its present configuration. Some other estimates advocate a considerably smaller ice extent at LGM, maybe only insignificantly larger than today's in some parts of Antarctica (Mayewski 1975; Colhoun \& Adamson 1992; Colhoun et al. 1992; Goodwin 1993; Hayashi \& Yoshida 1994). A recent review of Antarctic glacial history since the LGM (Ingólfsson, Hjort, Berkman et al. 1998) suggests that while ice extended well offshore around most of Antarctica at LGM, it did not extend all the way to the shelf break off East Antarctica and in the western Ross Sea, and that some East Antarctic coastal oases were probably ice-free. One interpretation of Antarctic ice-core data suggests that during LGM accumulation rates in interior Antarctica were 50-60\% lower than mean Holocene rates (Raisbeck et al. 1987; Jouzel et al. 1989), and that LGM ice thickness in interior East Antarctica was less than during the Holocene (Raynaud \& Lebel 1979; Martinerie et al. 1994).

Lacking good estimates of Antarctic ice volumes at LGM, an alternative way to examine the Antarctic contribution to post-LGM sea level rise is to look at the chronology of deglaciation and compare that with the Northern Hemisphere devel- opment. If the deglaciation history of Antarctica differs substantially from that in the north, the Antarctic contribution might show up as a watervolume input causing global sea level rise at a time when contribution from Northern Hemisphere ice sheets was unlikely. Thus a minimum estimate of the Antarctic contribution should be possible.

\section{The Northern Hemisphere deglaciation}

\section{The Laurentide and Cordilleran ice sheets}

The deglaciation of the North American ice sheets mainly took place between 16-8 Kya (Dyke \& Prest 1987a; Fulton 1989; Lundqvist \& Saarnisto 1995). The Cordilleran Ice Sheet retreated rapidly after $15 \mathrm{Kya}$, and disappeared between $10-8 \mathrm{Kya}$ (Dawson 1992; Lundqvist \& Saarnisto 1995). According to Dyke \& Prest $(1987 \mathrm{a}$, b), the Laurentide Ice Sheet began retreating between 17-14 Kya. Between 13-11 Kya ice retreat and thinning accelerated. Huge proglacial lakes, the most important of which was Lake Agassiz, developed, and large volumes of meltwater were discharged into the Gulf of Mexico (Teller 1990). Between 11-10 Kya ice retreat caused the drainage of Lake Agassiz to change, so that its meltwater was discharged into the western North Atlantic. By ca. 8 Kya the Laurentide Ice Sheet disintegrated over Hudson Bay and the last documented major 
meltwater input through the Hudson Strait into the North Atlantic was a huge drainage event from glacial lakes Ojibway and Agassiz in connection with the Hudson dome collapse (Dyke \& Prest 1987a; Andrews 1989, 1994). After 8 Kya much of the ice retreat was associated with ice stagnation and by $7.2-7 \mathrm{Kya}$ only small remnants of the Laurentide Ice Sheet still existed in Labrador and on Baffin and Melville islands (Dyke \& Prest 1987a, b, c; Andrews, Mclean et al. 1995). Likewise, only small remnants of the Inuit ice sheet of north-eastern Arctic Canada remained by 87 Kya. A comparison between the deglaciation history and the regional $\partial^{18} \mathrm{O}$ isotope record from the south-eastern Baffin Island shelf suggests a rapidly decreasing meltwater input to Hudson Bay and Labrador Sea after 8 Kya (Andrews, Erlenkeuser et al. 1991).

\section{The ice sheets of Greenland and Iceland}

The Late Weichselian-early Holocene glacial history of Greenland was recently reviewed by Funder \& Hansen (1996). They suggested that the initial retreat of the Greenland Ice Sheet after LGM was caused by rising global sea level, destabilizing marine portions of the ice sheet. The period between 10-9.5 Kya was characterized by unstable ice margins, with glacial re-advances in many parts of the country (Funder et al. 1998). However, after $9.5 \mathrm{Kya}$ the ice margins retreated rapidly, and by 8-7 Kya the present distribution of ice cover was attained around Greenland (Funder 1989). The Icelandic Ice Sheet retreated to positions inside the present coast already by $13-12 \mathrm{Kya}$, but experienced considerable ice re-advances between 11 $10 \mathrm{Kya}$ (Ingólfsson \& Norddahl 1994). After $10 \mathrm{Kya}$ the Icelandic Ice Sheet retreated and thinned very rapidly, and by $8 \mathrm{Kya} \mathrm{BP}$ the Icelandic glaciers were of a similar size or smaller than today (Ingólfsson, Björck et al. 1997).

\section{The Scandinavian-British Ice Sheet}

In Scandinavia and the British Isles ice thinning and retreat was under way by $16 \mathrm{Kya}$ (Dawson 1992), and the deglaciation of the British Isles was complete by ca. 10 Kya (Walker et al. 1994). By 10 Kya coastal Norway, southern Sweden and south-easternmost Finland were deglaciated (Birks et al. 1994; Lundqvist \& Saarnisto 1995). After $10 \mathrm{Kya}$ the Scandinavian inland ice retreated and thinned very rapidly. By 9 Kya remnants of the ice sheet lingered in the Norwegian-Swedish mountain range and on the lowlands of central northern Sweden, but by $8.5 \mathrm{Kya}$ only minor ice fields remained in the high mountains of northern Sweden (Lundqvist \& Saarnisto 1995).

\section{The Barents Sea and Kara Sea ice sheets}

There is good evidence for an ice sheet grounded over much of the Barents Sea shelf during the Late Weichselian (Elverhøi \& Solheim 1983; Polyak et al. 1995). The Barents Sea Ice Sheet was centred over the northern Barents Sea and eastern Svalbard (Salvigsen 1981; Forman 1990), but probably expanded across Spitsbergen and terminated beyond the present coastline of Svalbard (Forman 1989; Mangerud et al. 1992; Landvik, Bondevik et al. 1998). Recent studies suggest relatively limited ice volumes over Novaya Zemlya and the Kara Sea during the Late Weichselian (Forman, Lubinski et al. 1995; Astakhov 1998; Svendsen et al. 1999; Forman, Ingólfsson et al. 1999). Deglaciation from the shelf areas was under way by $14-13 \mathrm{Kya}$, and by 10-9.5 Kya these marine-based ice sheets had completely disintegrated. Glaciers on Svalbard were at or behind their present margins before $9 \mathrm{Kya}$ (Salvigsen 1981; Landvik, Bondevik et al. 1998).

\section{Small ice caps and mountain glaciers}

The combined volume of ice in glaciers and small ice caps in the mountain ranges of Europe, North America, the Himalayas, South American Andes, as well as in New Zealand, Tasmania and in the high mountains in Africa and New Guinea during the last glacial maximum has been estimated to equal a global sea level change of about $5.5 \mathrm{~m}$ (Hughes et al. 1981). Since most of these had melted away already by 10 Kya (Denton \& Hughes 1981; Clapperton 1990; Dawson 1992; Rutter 1995) or shortly thereafter, they did not significantly contribute to global sea level rise in Holocene times.

\section{The Antarctic deglaciation}

There have been different views as to whether the reduction of the Antarctic Ice Sheet since the LGM preceded, was in phase with, or lagged behind the Northern Hemisphere deglaciation (Nakada \& Lambeck 1988; Colhoun et al. 1992; Hjort, Ingólfsson et al. 1997). The prevailing view has been that the East Antarctic Ice Sheet remained 
relatively stable during the transition from LGM to the Holocene, whereas the West Antarctic Ice Sheet experienced some major changes (Stuiver et al. 1981), and further, that fluctuations of the West Antarctic Ice Sheet were broadly synchronous with ice sheets in the Northern Hemisphere (Clapperton \& Sugden 1988; Broecker \& Denton 1990; Clapperton 1990; Dawson 1992). These views have been increasingly challenged by results coming from different regions around Antarctica (e.g. Barsch \& Mäusbacher 1986; Domack et al. 1991; Ingólfsson, Hjort, Björck et al. 1992; Goodwin 1993; Verkulich \& Hiller 1994; Björck, Håkansson et al. 1996; Björck, Hjort et al. 1996; Licht et al. 1996; Shevenell et al. 1996; Colhoun 1997; Hjort, Ingólfsson et al. 1997; Hjort, Björck et al. 1998; Zwartz et al. 1998). Recently Ingólfsson, Hjort, Berkman et al. (1998) examined the circumantarctic glacial history evidence on land, related to developments after the LGM. The purpose was to check if a general Antarctic glacial history pattern could be identified, and to highlight the question of the relative timing of deglaciation in Antarctica versus that of the large Northern Hemisphere ice sheets. They recognized a broad pattern in the glacial histories from the coastal sites around Antarctica (Fig. 2):

a) Ice extended offshore around most of Antarctica at LGM, though some oases may have remained ice free. But the LGM ice sheet did not reach the shelf break off East Antarctica or in the western Ross Sea or along the southernmost parts of the Antarctic Peninsula. Ice retreat from the LGM positions was under way by $17-14 \mathrm{Kya}$, and by 11-10 Kya initial deglaciation of some inner shelf areas as well as a few outer coastal land areas had occurred. The ice retreat from LGM positions around Antarctica was probably eustatically controlled. Melting Northern Hemisphere glaciers caused global sea level to rise and the Antarctic grounding lines and ice fronts gradually retreated from the outer shelf towards the continent.

b) Deglaciation of some shallow inner shelf areas and of most presently ice-free land areas, with the exception of some East Antarctic oases, occurred between ca. 10-5 Kya. After the receding glaciers had reached the edges of most of the presently icefree land areas or shallow inner shelf areas at 10$8 \mathrm{Kya}$, the rate of deglaciation slowed - and sometimes reversed into glacial re-advances. It was not until around or shortly after 5 Kya that most Antarctic glaciers had retreated to or behind their present positions. Some areas seem to have become ice-free as late as ca. $3 \mathrm{Kya}$, and the grounding line of the Ross Ice Shelf continued retreating until ca. $2.5 \mathrm{Kya}$.

c) This gradual deglaciation between 10-5 Kya was most likely controlled by a globally seen delayed interglacial warming in Antarctica. The warming peaked late, in a hypsithermal event visible in the records between 4.7-2 Kya. The best documented records put it between 4-3 Kya, in the Antarctic Peninsula region, and between 3.6$2.6 \mathrm{Kya}$ in coastal Victoria Land. Many records

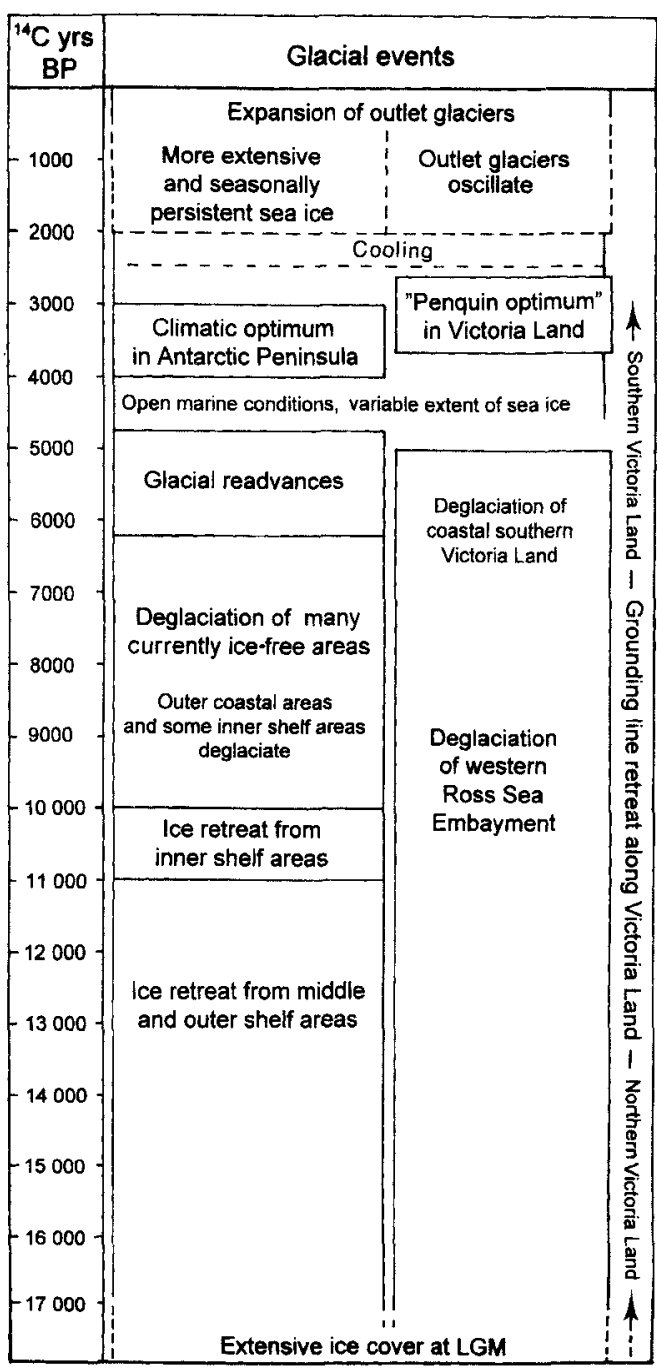

Fig. 2. A broad synthesis of the deglaciation of Antarctica and associated environmental developments since the LGM (slightly modified from Ingólfsson, Hjort, Berkman et al. 1998). 
Fig. 3. (a) Timing of deglaciation and meltwater input to the oceans from the Northern Hemisphere and Antarctic ice sheets. Whole columns indicate substantial input; broken columns indicate minor input. Northern Hemisphere input diminishes rapidly after $10 \mathrm{Kya}$, and by $8 \mathrm{Kya}$ onjy the Laurentide lce Sheet continues to contribute significant meltwater. After ca. 7 Kya the Antarctic Ice Sheet is the only plausible major meltwater source. (b) Sea level rise after $9 \mathrm{Kya}$, according to the Barbados sea level curve of Fairbanks (1989) and the sea level data from Australian Morley Island core (Eisenhauer et al. 1993) and the Papua New Guinea Huon Peninsula core (Chappell \& Polach 1991). Although large (ca $10 \mathrm{~m}$ ) differences of apparent sea level depth at $6 \mathrm{Kya}$ can be observed between the Australian and New Guinea data and the Barbados curve, the combined data indicate considerable sea level rise between ca. 8-5 Kya. The differences in apparent sea evel depth have been explained as resulting from water redistribution due to changes in the Earth's geoid after 6 Kya (Eisenhauer et al. 1993). Period between 7-5 Kya. when the Littorina-Tapes transgressions are recorded in Scandinavia and where the Antarctic meltwater input shows strongly, is marked with broken lines between (a) and (b).

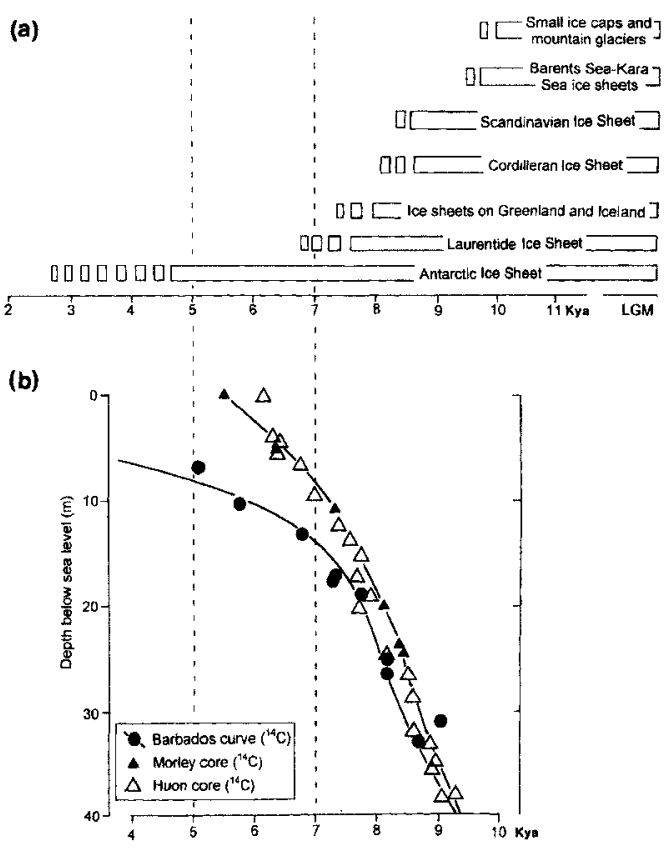

pared to the Northern Hemisphere deglaciation, we suggest that this late Antarctic deglaciation caused part of the global sea level rise between 8$7 \mathrm{Kya}$ and most of it between 7-5 Kya (Fig. 3).

Well-dated relative sea level records, e.g. from Scandinavia, Svalbard and Greenland, show marine transgressions in the broad interval 8-4 Kya (Hjort 1973, 1981; Forman 1990; Pirazzoli 1991; Donner 1995). Raised beaches of the LittorinaTapes transgression of Scandinavia define a zone of high relative sea level, thought to have peaked at 7-6 Kya (Møller 1986; Donner 1995). In Svalbard, the mid-Holocene sea level record is characterized by a transgression, broadly dated between 6.5-5 Kya (Forman, Mann et al. 1987; Landvik, Mangerud et al. 1987; Forman 1990). Hjort $(1973,1981)$ described the Vega transgression in East Greenland, culminating shortly after $6 \mathrm{Kya}$, and Mid-Holocene transgressions or peaks in relative sea levels, broadly dated between 7$4 \mathrm{Kya}$, have been reported from many sites around the globe, both inside and outside the former glaciated areas (Pirazzoli 1991). A relative sea level fall of 1-2 $\mathrm{m}$ has been recorded at many sites since the mid-Holocene sea level high stand (Pirazzoli 1991). This relative sea level lowering has been attributed to the visco-elastic response of the Earth's mantle following increased water-load on the sea floor and the redistribution of the 
meltwater by isostatic and gravitational forcing (Clark \& Lingle 1979; Nakada \& Lambeck 1988; Mitrovica \& Peltier 1991; Tushingham \& Peltier 1991; Zwartz et al. 1998). Goodwin (1998) suggested that the late Holocene increase in Antarctic ice volumes might account for about $1 \mathrm{~m}$ of the sea level lowering.

Relative sea level is highly variable in both space and time, and there are a number of processes which can influence changes in the eustatic sea level. As pointed out by Kidson (1982), and emphasized by Pirazzoli (1991) and Eisenhauer et al. (1993), separating the eustatic, tectonic, glacio-isostatic, hydro-isostatic and geoidal components of sea level change is so complex that a universal eustatic curve is not possible to achieve. According to the Barbados sea level curve of Fairbanks (1989), eustatic sea level rose by ca. $17 \mathrm{~m}$ between 8 $5 \mathrm{Kya}$, of which there was a ca. $8 \mathrm{~m}$ rise between $7-$ $5 \mathrm{Kya}$. The Morley Island curve (Eisenhauer et al. 1993), from off the west coast of Australia, and the Huon Peninsula curve (Chappell \& Polach 1991), from Papua New Guinea, indicate about $10 \mathrm{~m}$ and $16 \mathrm{~m}$ of sea level rise after $8 \mathrm{Kya}$, respectively. The Florida sea level curve of Toscano \& Lundberg (1998) suggests that sea level there rose by ca. $6 \mathrm{~m}$ between $8-5 \mathrm{Kya}$, of which about $4 \mathrm{~m}$ occurred between $7-5 \mathrm{Kya}$. Although caution should be exercised when relating the mid-Holocene transgressions to an increase in the mass of ocean water, there seems to be a consensus that post-glacial sea level rise due to melting of continental ice masses shows strongly in the sea level curves prior to $5 \mathrm{Kya}$ when it is assumed to have been completed (Pirazzoli 1991). The Littorina-Tapes transgressions in Scandinavia have been interpreted as caused by the interplay between the slowing down of isostatic uplift and the continued relatively rapid eustatic rise of sea level due to meltwater input to the oceans from the vanishing Pleistocene ice sheets (Donner 1995). As noted above, the Northern Hemisphere ice sheets could not have caused much glacio-eustatic rise of sea level after 8-7 Kya, since they had mostly disappeared by that time. The Antarctic Ice Sheet is the only plausible candidate for a major input of meltwater to the oceans between 7-5 Kya, leading to the global midHolocene sea level high stand and causing transgressions like the Tapes-Littorina transgression in Scandinavia.

Acknowledgements. - Our research in Antarctica, with four field expeditions over the past 12 years, has been generously supported by the Swedish Natural Science Research Council, the Swedish Polar Research Secretariat and the universities of Lund and Gothenburg. It has also benefited from logistic support from the Antarctic operators in Argentina, Germany and USA. Grants to Ó. Ingólfsson from OK's Miljöstiftelse and Stiftelsen Futura for palaeoenvironmental research in Antarctica during the 1994-95 season are gratefully acknowledged. We also thank the referees, John Andrews and Tore Påsse, for comments and suggestions which improved the manuscript.

\section{References}

Anderson, J. B., Shipp, S. S., Bartek, L. R. \& Reid, D. E. 1992: Evidence for a grounded ice sheet on the Ross Sea continental shelf during the late Pleistocene and preliminary paleodrainage reconstruction. Antarct. Res. Ser. 57, 39-62.

Andrews, J. T. 1989: Quaternary geology of the northeastern Canadian shield. In R. J. Fulton (ed.): Quaternary geology of Canada and Greenland. Pp. 276-301. Ottawa: Geological Survey of Canada.

Andrews, J. T. 1992: A case of missing water. Nature 358, 281. Andrews, J. T. 1994: Wisconsinan Late-glacial environmental change on the southeast Baffin Shelf, southeast Baffin Island and northern Labrador. J. Quat. Sci. 9, 179-183.

Andrews, J. T., Erlenkeuser, H., Evans, L. W., Briggs, W. M. \& Jull, A. J. T. 1991: Meltwater and deglaciation, SE Baffin Shelf (NE margin Laurentide Ice Sheet) between 13.5 and $7 \mathrm{ka}$ : from $\mathrm{O}$ and $\mathrm{C}$ stable isotopic data. Paleoceanography 6 , 621-637.

Andrews, J. T., Maclean, B., Kerwin, M., Manley, W., Jennings, A. E. \& Hall, F. 1995: Final stages in the collapse of the Laurentide Ice Sheet, Hudson Strait, Canada, NWT: ${ }^{14} \mathrm{C}$ AMS dates, seismic stratigraphy and magnetic susceptibility logs. Quat. Sci. Rev. 14, 983-1004.

Astakhov, V. 1998. The last ice sheet in the Kara Sea: terrestrial constraints on its age. Quat. Int. 45/46, 19-28.

Banfield, L. A. \& Anderson, J. B. 1995: Seismic facies investigation of the Late Quaternary glacial history of Bransfield Basin, Antarctica. Ant. Res. Ser. 68, 123-140.

Barsch, D. \& Mäusbacher, R. 1986: Beiträge zur Vergletscherungsgeschichte und zur Reliefentwicklung der Südshetland Insel. (Contribution to the glacial history and topographical evolution of South Shetland Island.) Z. Geomorphol. 61, 2537.

Birks, H. H., Paus, A., Svendsen, J. I., Alm. T., Mangerud, J. \& Landvik, J. Y. 1994: Late Weichselian environmental change in Norway, including Svalbard. J. Quat. Sci. 9, 133-145.

Björck, S., Hăkansson, H.. Olsson, S., Ellis-Evans, C., Humlum, O. \& Lirio, J. M. 1996: Late Holocene palaeoclimatic records from lake sediments on James Ross Island, Antarctica. Palaeogeogr., Palaeoclimatol., Palaeoecol. 113, 195-220.

Björck, S., Hjort, C., Ingólfsson, Ó., Zale, R. \& Ising, J. 1996: Holocene deglaciation chronology from lake sediments. In J. López-Martinez et al. (eds.): Geomorphological map of Byers Peninsula, Livingston Island. Pp, 49-51. Cambridge: British Antarctic Survey.

Broecker, W. S. \& Denton, G. H. 1990: The role of oceanatmosphere reorganisations in glacial cycles. Quat. Sci. Rev. 9, 305-343

Chappell, J. \& Polach, H. 1991: Post-glacial sea level rise from a coral record at Huon Peninsula, Papua New Guinea. Nature 349. 147-149. 
Chappell, J. \& Shackleton, N. J. 1986: Oxygen isotopes and sea level. Nature 324, 137-140.

Clapperton, C. M. 1990: Quaternary glaciations in the Southern Ocean and Antarctic Peninsula area. Quat. Sci. Rev. 9, 229 252.

Clapperton, C. M. \& Sugden, D. E. 1988: Holocene glacier fluctuations in South America and Antarctica. Quat. Sci. Rev. 7, 185-198

Clark, J. A. \& Lingle, C. S. 1979: Predicted sea level changes $(18,000$ years BP to present) caused by late-glacial retreat of the Antarctic Ice Sheet. Quat. Res. 9, 265-287.

Clark, P. U., Alley, R. B., Keigwin, L. D., Licciardi, J. M., Johnsen, S. J. \& Wang, H. 1996: Origin of the first global meltwater pulse following the last glacial maximum. Paleoceanography 11, 563-577.

Colhoun, E. A. 1997: A review of geomorphological research in Bunger Hills and expansion of the East Antarctic Ice Sheet during the Last Glacial Maximum. In C. A. Ricci (ed.): The Antarctic region: geological evolution and processes. Pp. 801-807. Siena: Universtà degli Studi di Siena.

Colhoun, E. A. \& Adamson, D. A. 1992: The Quaternary history of the Bunger Hills, East Antarctica. In Y. Yoshida et al. (eds.): Recent progress in Antarctic earth science. Pp. 745750. Tokyo: Terra Scientific Publishing.

Colhoun, E. A., Mabin. M. C. G., Adamson, D. A. \& Kirk. R. M. 1992: Antarctic ice volume and contribution to sea level fall at 20,000 yr BP from raised beaches. Nature 358, 316-319.

Dawson, A. G. 1992: Ice Age Earth. 293 pp. London: Routledge.

Denton, G. H. 1979: Glacial history of the Byrd-Darwin Glacier area, Transantarctic Mountains. Antarct. J. U. S. 14, 57-58.

Denton, G. H. \& Hughes, T. J. (eds.) 1981: The last great ice sheets. 484 pp. New York: John Wiley and Sons.

Denton, G. H., Prentice, M. L. \& Burckle, L. H. 1991: Cainozoic history of the Antarctic Ice Sheet. In R. J. Tingey (ed.): Geology of Antarctica. Pp. 365-433. Oxford: Oxford University Press.

Domack, E. W., Jull, A. J. T. \& Nako, S. 1991: Advance of East Antarctic outlet glaciers during the Hypsithermal: implications for the volume state of the Antarctic Ice Sheet under global warming. Geology 19, 1059-1062.

Donner, J. 1995: The Quaternary history of Scandinavia. 200 pp. Cambridge: Cambridge University Press.

Drewry, D. J., Jordan, S. R. \& Jankowski, E. 1982: Measured properties of the Antarctic Ice Sheet: surface configurations, ice thickness, volume and bedrock characteristics. Ann. Glaciol. 3, 83-91.

Dyke, A. S. \& Prest, V. K. 1987a: Late Wisconsinan and Holocene history of the Laurentide Ice Sheet. Geogr. Phys. Quat. 41, 237-263.

Dyke, A. S. \& Prest, V. K. 1987b: Late Wisconsinan and Holocene retreat of the Laurentide Ice Sheet. Geological Survey of Canada, Map 1702A; scale 1:5000 000.

Dyke, A. S. \& Prest, V. K. 1987c: Paleogeography of northern North America, $18000-5000$ years ago. Geological Survey of Canada, Map 1703A; scale 1:12500000.

Eisenhauer, A., Wasserburg, G. J., Chen, J. H.. Bonani, G., Collins, L. B., Zhu, Z. R. \& Wyrwoll, K. H. 1993: Holocene sea level determination relative to the Australian continent: U/Th (TIMS) and ${ }^{14} \mathrm{C}$ (AMS) dating of coral cores from the Abrolhos Islands. Earth Planet. Sci. Lett. 114, 529-547.

Elverhøi. A. \& Solheim. A. 1983: The Barents Sea Ice Sheet, a sedimentological discussion. Polar Res. 1, 23-32.
Fairbanks, R. G. 1989: A 17,000-year glacio-eustatic sea leve record: influence of glacial melting rates on the Younger Dryas event and deep-ocean circulation. Nature 342, 637642.

Forman, S. L. 1989: Late Weichselian glaciation and deglaciation of the Forlandsund area, western Spitsbergen, Svalbard. Boreas 18, 51-61.

Forman, S. L. 1990: Post-glacial relative sea level history of northwestern Spitsbergen, Svalbard. Bull. Geol. Soc. Am. 102, 1580-1590.

Forman, S. L., Mann, D. \& Miller, G. 1987: Late Weichselian and Holocene relative sea level history of Brøggerhalvøya. Spitsbergen. Quat. Res. 27, 41-51.

Forman, S. L., Lubinski, D., Miller, G. H., Snyder, J., Matishov, G., Korsun, S. \& Myslivets, V. 1995: Postglacial emergence and distribution of Late Weichselian ice-sheet loads in the northern Barents and Kara seas, Russia. Geology 23, 113116.

Forman, S. L., Ingólfsson, Ó., Gataullin, V., Manley, W. F. \& Lokrantz, H. 1999: Late Quaternary stratigraphy of western Yamal Peninsula, Russia: new constraints on the configuration of the Eurasian Ice Sheet. Geology 27, 803-806.

Fulton, R. J. (ed.) 1989: Quaternary geology of Canada and Greenland. 839 pp. Ottawa: Geological Survey of Canada.

Funder, S. 1989: Quaternary geology of the ice-free areas and adjacent shelves of Greenland. In R. J. Fulton (ed.): Quaternary geology of Canada and Greenland. Pp. 741 792. Ottawa: Geological Survey of Canada.

Funder, S. \& Hansen, L. 1996: The Greenland ice sheet - a model for its culmination and decay during and after the last glacial maximum. Bull. Geol. Soc. Den. 42, 137-152.

Funder, S., Hjort, C., Landvik, J. Y., Nam, S. I. Reeh, N. \& Stein, R. 1998: History of a stable ice margin - East Greenland during the Middle and Upper Pleistocene. Quat. Sci. Rev. 17, 77-123.

Goodwin, I. D. 1993: Holocene deglaciation, sea level change, and the emergence of the Windmill Islands, Budd Coast, Antarctica. Quat. Res. 40, 70-80.

Goodwin, I. D. 1998: Did changes in Antarctic ice volume influence late Holocene sea level lowering? Quat. Sci. Rew. $17,319-322$

Hall, B. L. 1997: Geological assessment of Antarctic ice sheet stability. Ph.D. thesis, University of Maine, Orono (USA).

Harris, P. T., Howard, W., O'Brien, P. E., Sedgwick, P. N. \& Sikes, E. L. in press: Quaternary Antarctic ice-sheet fluctuations and Southern Ocean palaeoceanography: natural variability studies at the Antarctic CRC. AGSO J. Aust. Geol. Geophys.

Hayashi, M. \& Yoshida, Y. 1994: Holocene raised beaches in the Luitzow-Holm Bay region, East Antarctica. Mem. Natl. Inst. Polar Res. Special Issue 50, 49-84.

Hjort, C. 1973: The Vega Transgression. A hypsithermal event in central East Greenland. Bull. Geol. Soc. Den. 22, 25-38.

Hjort, C. 1981: Present and middle Flandrian coastal morphology in northeast Greenland. Nor. Geogr. Tidsskr. 35, 197 207

Hjort. C., Björck. S., Ingólfsson, Ó. \& Möller, P. 1998: Holocene deglaciation and climate history of the northern Antarctic Peninsula region - a discussion of correlations between the Southern and Northern Hemispheres. Ann. Glaciol. 27, 110-112.

Hjort, C., Ingólfsson, Ó., Möller, P. \& Lirio, J. M. 1997: Holocene glacial history and sea level changes on James Ross Island, Antarctic Peninsula. J. Quat. Sci. 12, 259-273. 
Hughes, T. J., Denton, G. H., Andersen, B. G., Schilling, D. H., Fastook, J. L. \& Lingle, C. S. 1981: The last great ice sheets: a global view. In G. H. Denton \& T. J. Hughes (eds.): The last great ice sheets. Pp. 263-317. New York: John Wiley and Sons.

Huybrechts, P. 1990a: The Antarctic Ice Sheet during the last glacial-interglacial cycle: a three-dimensional experiment. Ann. Glaciol. 14, 115-119.

Huybrechts, P. 1990b: A 3-D model for the Antarctic Ice Sheet: A sensitivity study on the glacial-interglacial contrast. Clim. Dyn. 5, 79-92.

Ingólfsson, Ó. \& Norddahl, H. 1994: A review of the environmental history of Iceland, $13000-9000$ yr BP. $J$. Quat. Sci. 9, 147-150.

Ingólfsson, Ó., Björck, S., Haflidason, H. \& Rundgren, M. 1997: Glacial and climatic events in Iceland reflecting regional North Atlantic climatic shifts during the PleistoceneHolocene transition. Quat. Sci. Rev. 16, 1135-1144.

Ingólfsson, Ó., Hjort, C., Berkman, P. A., Björck, S., Colhoun, E., Goodwin, I, D., Hall, B., Hirakawa, K, Melles, M., Möller, P. \& Prentice, M. L. 1998: Antarctic glacial history since the Last Glacial Maximum: an overview of the record on land. Antarct. Sci. 10(3), 326-344.

Ingólfsson, Ó., Hjort, C., Björck, S. \& Smith, R. I. L. 1992: Late Pleistocene and Holocene glacial history of James Ross Island, Antarctic Peninsula. Boreas 21, 209-222.

Jouzel, J., Raisbeck, G., Benoist, J. P., Yiou, F., Lorius, C., Raynaud, D., Petit, J. R., Barkov, N. I., Korotkevich, Y. S. \& Kotlyakov, V. M. 1989: A comparison of deep Antarctic ice cores and their implications for climate between 65,000 and 15,000 years ago. Quat. Res. 31, 135-150.

Kellogg, T. B., Hughes, T. \& Kellogg, D. E. 1996: Late Pleistocene interactions of East and West Antarctic ice-flow regimes: evidence from the McMurdo Ice Shelf. J. Glaciol. $42,486-500$.

Kidson, C. 1982. Sea level changes in the Holocene. Quat. Sci. Rev. I, 121-151.

Landvik, I. Y., Bondevik, S., Elverhøi, A., Fjeldskaar, W., Mangerud, J., Siegert, S., Salvigsen, O., Svendsen, J. I. \& Vorren, T. 1998: The Last Glacial Maximum of Svalbard and the Barents Sea area: ice sheet extent and configuration. Quat. Sci. Rev. 17, 43-75.

Landvik, J. Y., Mangerud, J. \& Salvigsen, O. 1987: The Late Weichselian and Holocene shoreline displacement on the west-central coast of Svalbard. Polar Res. 5, 29-44.

Licht, K. J., Jennings, A. E., Andrews, J. T. \& Williams, K. M. 1996: Chronology of the late Wisconsin ice retreat from the western Ross Sea, Antarctica. Geology 24, 223-226.

Lundqvist, J. \& Saarnisto, M. 1995. Summary of project IGCP253. Quat. Int. 28, 9-18.

Mangerud, J., Bolstad, M., Elgersma, A., Helliksen, D., Landvik, J. Y., Lønne, I., Lycke, A. K., Salvigsen, O., Sandahl, T. \& Svendsen, J. I. 1992: The Last Glacial Maximum on Spitsbergen, Svalbard. Quat. Res. 38, 1-31.

Martinerie, P., Lipenkov, V. Y., Raynaud, D., Chappellaz, J., Barkov, N. I. \& Lorius, C. 1994: Air content palaeorecord in the Vostok ice core (Antarctica): a mixed record of climatic and glaciological parameters. J. Geophys. Res. 99, 10565-10576.

Mayewski, P. A. 1975: Glacial geology and late Cenozoic history of the Transantarctic Mountains, Antarctica. Inst. Polar Stud. Rep. 56, 1-168.

Mitrovica, J. X. \& Peltier, W. R. 1991: On postglacial geoid subsidence over the equatorial oceans. J. Geophys. Res. 96, 20053-20071.
Møller, J. J. 1986: Holocene transgression maximum about 6000 years BP at Ramså, Vesterålen, north Norway. Nor. Geogr. Tidsskr. 40, 77--84.

Nakada, M. \& Lambeck, K. 1988: The melting history of the late Pleistocene Antarctic Ice Sheet. Nature 333, 36-40.

Peltier, W. R. 1994: Ice Age paleotopography. Science 265, 195-201.

Pirazzoli, P. A. 1991: World Atlas of Holocene sea level changes. 300 pp. Amsterdam: Elsevier.

Polyak, L. S., Lehman, S. J., Gataullin, V. \& Jull, A. J. T. 1995: Two-step deglaciation of the southeastern Barents Sea. Geology 23, 567-571.

Raisbeck, G. M., Yiou, F., Bourles, D., Lorius, C., Jouzel, J. \& Barkov, N. I. 1987: Evidence for two intervals of enhanced ${ }^{10} \mathrm{Be}$ concentrations in Antarctic ice during the last glacial period. Nature 326, 273-277.

Raynaud, D. \& Lebel, B. 1979: Total gas content and surface elevation of polar ice sheets. Nature 281, 289-291.

Rutter, N. 1995: Problematic ice sheets. Quat. Int. 28, 19-37.

Salvigsen, O. 1981: Radiocarbon dated raised beaches and glacial history of the northern coast of Spitsbergen, Svalbard. Polar Res. 1, 97-115.

Shevenell, A. E., Domack, E. W. \& Kernan, G. M. 1996: Record of Holocene palaeoclimate change along the Antarctic Peninsula: evidence from glacial marine sediments, Lallemand Fjord. Pap. Proc. R. Soc. Tasm. 130, 55-64.

Stuiver, M., Denton, G. H., Hughes, T. J. \& Fastook, J. L. 1981: History of the marine ice sheet in West Antarctica during the last deglaciation: a working hypothesis. In G. H. Denton \& T. J. Hughes (eds.): The last great ice sheets. Pp. 319-436. New York: John Wiley and Sons.

Svendsen, J. I., Astakhov, V. I., Bolshiyanov, D. Y., Demidov, I., Dowdeswell, J. A., Gataullin, V., Hjort, C., Hubberten, H. W., Larsen, E., Mangerud, J., Melles, M.. Möller, P., Saarnisto, M. \& Siegert, M. J. 1999: Maximum extent of the Eurasian ice sheets in the Barents and Kara Sea region during the Weichselian. Boreas 28, 234-242.

Teller, J. T. 1990: Meltwater and precipitation runoff to the North Atlantic, Arctic and the Gulf of Mexico from the Laurentide ice sheet and adjacent regions during the Younger Dryas. Paleoceanography 5, 897-905.

Toscano, M. A. \& Lundberg, J. 1998: Early Holocene sea level record from submerged fossil reefs on the southeast Florida margin. Geology 26, 255-258.

Tushingham, A. M. \& Peltier, W. R. 1991: Ice-3G: a new global model of late Pleistocene deglaciation based upon geophysical predictions of postglacial relative sea level change. $J$. Geophys. Res. 96, 4497-4523.

Verkulich, S. R. \& Hiller, A. 1994: Holocene deglaciation of Bunger Hills revealed by ${ }^{14} \mathrm{C}$ measurements on stomach oil deposits in snow petrel colonies. Antarct. Sci. 6, 395-399.

Walker, M. J. C., Bohncke, S. J. P., Coope, G. R., O'Connell, M., Usinger, H. \& Verbruggen, C. 1994: The Devensian/ Weichselian Late-glacial in northwest Europe (Ireland, Britain, north Belgium, The Netherlands, northwest Germany). J. Quat. Sci. 9, 109-118.

Zhang, Q. S. 1992: Late Quaternary environmental changes in the Antarctic and their correlation with global change. In Y. Yoshida et al. (eds.): Recent progress in Antarctic earth science. Pp. 781-785. Tokyo: Terra Scientific Publishing.

Zwartz, D., Bird, M., Stone, M. \& Lambeck, K. 1998: Holocene sea level change and ice-sheet history in the Vestfold Hills, East Antarctica. Earth. Planet. Sci. Lett. 155, 131-145. 